\title{
Food restriction beginning at lactation interferes with the cellular dynamics of the mucosa and colonic myenteric innervation in adult rats
}

\author{
JOÃO PAULO F. SCHOFFEN ${ }^{1}$, FERNANDO A. VICENTINI ${ }^{2}$, CAROLINA G. MARCELINO ${ }^{1}$, \\ EDUARDO J.A. ARAÚJO ${ }^{3}$, MARIA M.D. PEDROSA ${ }^{4}$ and MARIA R.M. NATALI ${ }^{2}$ \\ ${ }^{1}$ Centro de Ciências Biológicas, Universidade Estadual do Norte do Paraná/UENP, \\ Rodovia BR-369, Km 54, Vila Maria, 86360-000 Bandeirantes, PR, Brasil \\ ${ }^{2}$ Departamento de Ciências Morfológicas, Universidade Estadual de Maringá/UEM, \\ Av. Colombo, 5790, 87020-900 Maringá, PR, Brasil \\ ${ }^{3}$ Departamento de Histologia, Universidade Estadual de Londrina/UEL, \\ Rodovia Celso Garcia Cid - PR-445, Km 380, 86051-980 Londrina, PR, Brasil \\ ${ }^{4}$ Departamento de Ciências Fisiológicas, Universidade Estadual de Maringá/UEM, \\ Av. Colombo, 5790, 87020-900 Maringá, PR, Brasil \\ Manuscript received on April 8, 2014; accepted for publication on June 30, 2014
}

\begin{abstract}
The effects of food restriction (FR) on the morphoquantitative aspects of the wall and myenteric neurons of the proximal colon in adult rats were analysed. FR was imposed by duplication of the experimental brood size in relation to the control brood during lactation. The FR group received a $50 \%$ reduction of food from weaning until 90 days of age. Samples of the colon underwent histological processing to morphometrically analyze the crypts, muscularis mucosae, tunica mucosa, and muscularis externa. We determined the number of goblet cells and serotoninergic enteroendocrine cells, and morphoquantitatively studied the myenteric neuronal population. FR caused hypertrophy in the tunica mucosa, increase in crypt depth and in the muscular layer of the mucosa, a decrease in the thickness of the tunica muscularis and in the number of goblet cells and an increase in serotoninergic cells. A higher neuronal density in the ganglia and a reduction of the cell profile area were observed in the FR group. FR imposed since lactation led to hypertrophy of the tunica mucosa, a reduction of neutral mucin production, atrophy of the tunica muscularis, and an increase in the survival neuronal in adult rats, attributable to an increase in the number of serotoninergic enteroendocrine cells in mucosa.
\end{abstract}

Key words: enteroendocrine cells, food restriction, goblet cells, intestinal morphology, myenteric neurons, serotonin.

\section{INTRODUCTION}

The large intestine is the last portion of the gastrointestinal tract (GIT) and plays a key role in hydroelectrolytic balance, in addition to participating in the formation and elimination of

Correspondence to: João Paulo Ferreira Schoffen

E-mail:jpschoffen@uenp.edu.br feces (Christensen 1989). It also secretes mucus for lubrication and protection and is involved in the nonenzymatic bacterial digestion of food (Ovalle and Nahirney 2008).

The colonic mucosa is lined with a single layer of cylindrical epithelial cells with different cell types distributed in deep intestinal crypts, including 
enterocytes involved in the fragmentation and final absorption of nutrients, stem cells for renewing the epithelium, mucus-secreting goblet cells, hormone-secreting enteroendocrine cells (Ovalle and Nahirney 2008), and undifferentiated cells.

The mucus that covers the epithelium represents the first line of intestinal mucosal defense against the invasion of antigens and bacteria that are present in the colonic lumen (Corfield et al. 2000, Mello et al. 2012). The protective effect provided by mucus is related to the presence of mucins (i.e., glycoproteins synthesized and secreted by goblet cells) (Gaudier et al. 2009). Any qualitative or quantitative changes in the secretion or expression patterns of mucins can affect the efficiency of the protective barrier, which can trigger important physiological and pathological consequences (Corfield et al. 2000).

The detection and response to components of the intestinal lumen involve intrinsic and extrinsic primary afferent neurons and the activation of reflex pathways. Such reflexes coordinate intestinal secretion and motility, resulting in a balance between the amount of nutrients digested and the absorption capacity of the intestine (Raybould 2002). There is no direct contact between nerve terminals and the luminal content; thus, the intestinal epithelium plays an important role in the transduction of nutritional signals through the intestinal wall (Berthoud and Neuhuber 2000). Specifically, enteroendocrine cells are specialized cells that act as sensory transducers in the epithelium of the intestinal mucosa by secreting serotonin (5-hydroxytryptamine [5HT]), an important neuroendocrine transmitter of the GIT (Gershon 2013). Changes in these cells or signaling mediated by 5-HT may result in intestinal dysmotility, visceral hypersensitivity, and secretomotor abnormalities (Crowell 2004).

The enteric nervous system (ENS) is responsible for the intrinsic innervation of the GIT. It is a division of the autonomic nervous system that regulates gastrointestinal function, including absorption, secretion, and motility (Hansen 2003).
The myenteric plexus, a major component of the ENS, is formed by a network of ganglia arranged in regular rows and interconnected by nerve fibers that extend from the esophagus to the anal canal. It is located between the circular and longitudinal layers of the muscularis externa and plays an essential role in the control of intestinal motility, among other functions (Hansen 2003, Furness 2006). Changes in the myenteric plexus may result in the development of various gastrointestinal disorders frequently caused by nutrient imbalance.

The effects of nutritional deficiencies on intestinal morphophysiology has spurred the interest of researchers for decades (Takano 1964, Firmansyah et al. 1989a, Natali and Miranda-Neto 1996, Franco et al. 2010). Previous studies have reported changes in intestinal absorptive patterns and motility (Takano 1964), morphological changes in intestinal size, changes in the thickness of the tunica mucosa and muscularis (Firmansyah et al. 1989a, Schoffen et al. 2005), changes in the number of goblet cells (Hermes et al. 2008b, Franco et al. 2010), and variations in the amount and size of myenteric neurons (Santer and Conboy 1990, Araújo et al. 2003, Natali et al. 2003, Hermes et al. 2008a) in animals subjected to nutritional deprivation at different ages and stages of life.

Numerous studies have evaluated the effects of dietary restriction on the mucosa and myenteric innervation of the small and large intestine in rats during pregnancy and lactation (Natali et al. 1995, Natali and Miranda-Neto 1996, Leite-Mello et al. 1997), a few days after weaning (Firmansyah et al. 1989a, b, Castelucci et al. 2002), in adulthood (Natali et al. 2003, Hermes et al. 2008a, b), and at older ages (Cowen et al. 2000, Schoffen et al. 2005, Porto et al. 2012). However, few studies have evaluated such parameters with a limited supply of food during pregnancy or lactation until adulthood (Firmansyah et al. 1989b, Santer and Conboy 1990). No studies of which we are aware of have morphoquantitatively analyzed 
the mucosa and certain cell types or intrinsic myenteric innervation of the large intestine in animals subjected to prolonged food restriction initiated soon after birth.

The goal of the present study was to assess the effects of food restriction (FR) imposed since lactation on the morphological and quantitative aspects of epithelial cell populations in the tunica mucosa and myenteric plexus neurons in the proximal colon in adult Wistar rats.

\section{MATERIALS AND METHODS}

\section{ANIMALS AND TREATMENT}

Pregnant Wistar rats were housed in individual cages. At birth, their broods were reorganized so that each mother had six (control [C] group) or twelve (food restriction [FR] group) male pups. The rats had free access to water and food (Nuvilab CR1; Nuvital, Curitiba, Brazil) during pregnancy and lactation. No puppy showed preference/ dominance for food.

The pups remained with their mothers until weaning at 21 days of age and were subsequently assigned to groups of four pups per box with free access to water. The rats in the $\mathrm{C}$ group were fed ad libitum, whereas the animals in the FR group were subjected to a $50 \%$ reduction of daily food intake (Vismara and Furlan 2007, Mazeti and Furlan 2008). This dietary pattern was maintained until 90 days of age. The establishment of the model was preliminarily performed at the Laboratory of Animal Physiology/ UEM, and the nutritional status of the animals was assessed, including the evolution of body weight, food intake, and glucose, total protein, and triglyceride levels (Vismara and Furlan 2007).

The animals used in this study were treated according to the ethical principles adopted by the Brazilian College of Animal Experimentation (COBEA) and approved by the Ethics Committee in Animal Experimentation of the Universidade Estadual de Maringá.

\section{TISSUE COLLECTION}

At 90 days of age, the rats were weighed and anesthetized with intraperitoneal sodium thiopental (Thionembutal; $40 \mathrm{mg} / \mathrm{kg}$ body weight). After laparotomy, the large intestine was collected, and its length was measured. Samples of the proximal colon, characterized by the end of the ileum-cecumcolic ampoule until the disappearance of mucosal oblique folds, were removed and underwent histological processing to morphologically analyze the colonic wall, morphometry of the tunica mucosa, crypt depth, muscularis mucosae, and muscularis externa and determine the number of goblet cells (acid and neutral mucins) and serotoninergic enteroendocrine cells. The Giemsa technique was used to morphoquantitatively study myenteric neurons.

\section{HistologicAL PROCESSING}

Samples of the proximal colon in the C and FR groups were opened on the mesocolic edge, washed with saline, and fixed in two solutions, Bouin and $4 \%$ paraformaldehyde. They were then dehydrated in serial ethanol solutions $(80 \%, 90 \%$, and $100 \%)$, cleared in xylene, and embedded in paraffin. The samples were cut in 6 and $5 \mu \mathrm{m}$ longitudinal semiserial histological sections using a Leica RM 2145 microtome. The $6 \mu \mathrm{m}$ slices were stained with hematoxylin-eosin (H\&E) to morphologically analyze the colonic wall and morphometry of the tunica mucosa, crypt depth, muscularis mucosae, and muscularis externa (Bouin-fixed samples).

For the morphometric analysis, we measured 100 points of the tunica mucosa, muscularis mucosae, and muscularis externa and 60 longitudinally oriented crypts in 10 histological sections per animal from images captured with a $10 \times$ objective lens on a BX41 Olympus light microscope coupled to an Olympus Q color 3 camera. The images were analyzed using Image-Pro Plus 4.5 software (Media Cybernetics). The results are expressed in micrometers. 
Histochemical Processing OF Goblet Cells

Bouin-fixed samples of the proximal colon were dehydrated, cleared, and semi-serially cut in $5 \mu \mathrm{m}$ thick sections for histochemical processing with Periodic Acid Schiff (PAS) and Alcian Blue (AB), $\mathrm{pH} 2.5$, of goblet cells that produce acid and neutral mucins, respectively.

The quantification of the goblet cell population was performed using Image-Pro Plus 4.5 software in 50 microscopic images $\left(0.352 \mathrm{~mm}^{2} /\right.$ field $)$ per animal per technique, captured with an Olympus BX41 light microscope coupled to an Olympus Q Color 3 camera with a $40 \times$ objective lens.

IMMUNOHISTOCHEMICAL PROCESSING OF SEROTONINERGIC

ENTEROENDOCRINE CELLS

From the samples of the proximal colon fixed in $4 \%$ paraformaldehyde, $6 \mu \mathrm{m}$ thick semiserial histological sections were made. After deparaffinization and hydration, the sections were treated with $3 \% \mathrm{H}_{2} \mathrm{O}_{2}$ in methanol for 10 min to eliminate endogenous peroxidase activity. After two washes with $0.1 \mathrm{M}$ phosphate-buffered saline (PBS; $\mathrm{pH}$ 7.4) for $5 \mathrm{~min}$, the sections were blocked with a solution that contained $10 \%$ goat serum for $10 \mathrm{~min}$. The tissues were then incubated with a solution that contained anti-serotonin primary antibody produced in rabbit (Sigma-Aldrich) diluted 1:100 in PBS for $1 \mathrm{~h}$. After two washes with 0.1 M PBS ( $\mathrm{pH}$ 7.4) for 5 min, the sections were incubated with biotinylated secondary antibody (anti-rabbit) for $10 \mathrm{~min}$, washed again, and treated with the streptavidin-peroxidase conjugate for $10 \mathrm{~min}$.

After further washes with PBS to remove excess enzyme conjugate, the immunohistochemical reaction was revealed by diaminobenzidine (DAB) in PBS and $\mathrm{H}_{2} \mathrm{O}_{2}$ for 15 min. After washing in distilled water, the sections were counterstained with hematoxylin, dehydrated in ethanol, cleared in xylene, and mounted under coverslips with Permount synthetic resin. All of the procedures were performed at room temperature.
The Histostain Plus Kit (Invitrogen) was used to perform this technique.

Immunoreactive serotoninergic enteroendocrine cells were quantified in the mucosa and crypts of the proximal colon in rats in the $\mathrm{C}$ and $\mathrm{FR}$ groups using Image-Pro Plus 4.5 software in 50 microscopic images $\left(0.352 \mathrm{~mm}^{2} /\right.$ field $)$ per animal, per technique, captured with an Olympus BX41 light microscope coupled to an Olympus Q Color 3 camera with a $40 \times$ objective lens.

\section{Disclosure of Myenteric PleXus Neurons}

The general population of myenteric neurons in the proximal colon was determined using the Giemsa staining method based on methylene blue (Barbosa 1978). For staining, the samples were rinsed in $0.9 \%$ saline solution and stored in Giemsa fixative. After fixation, whole-mount preparations of the muscle layer were obtained by removing the tunica mucosa, submucosa, and circular muscularis of samples of the proximal colon by dissection under a stereomicroscope with transillumination. The preparations were stained for $24 \mathrm{~h}$ using the Giemsa method in $0.1 \mathrm{~N}$ Sorensen phosphate buffer ( $\mathrm{pH}$ 6.9), at room temperature and protected from light. Subsequently, they were dehydrated in a series of increasing ethanol concentrations $(80 \%, 90 \%$, and $100 \%$ ), cleared in xylene, mounted on slides, and coverslipped with Permount synthetic resin.

\section{MORPHOQUANTITATIVE ANALYSIS OF NEURONS}

For the quantification of the myenteric neuronal population, we counted neuronal cell bodies by randomly sampling 40 ganglia per animal, per whole-mount preparations, in microscopic images captured in the intermediate and antimesocolic regions of the intestinal circumference (20 images per region), using a $40 \times$ objective lens. A myenteric ganglion was defined by considering the peripheral neurons visualized as the limit of the ganglia examined. This criterion was adopted to determine the number of neurons per ganglion. Individual 
neurons or small groups of 1-3 neurons were excluded from the counts.

From the captured images of ganglia, we randomly measured the area $\left(\mu \mathrm{m}^{2}\right)$ of the cell bodies of 100 neurons per animal (50 neurons per region), for a total of 500 cells per group. Only neuronal cell bodies with visible contour/boundary were measured. The neurons were ranked into class intervals of $150 \mu \mathrm{m}^{2}$ according to their size.

The image capturing of myenteric ganglia was performed with an Olympus BX41 light microscope coupled to an Olympus Q Color 3 camera, and the morphoquantitative analysis was performed using the Image-Pro Plus 4.5 image analysis software.

\section{STATISTICAL ANALYSES}

The numerical data were subjected to the Kolmogorov-Smirnov test to verify normality. For the parametric data, Student's $t$-test was applied. Morphometric data, ganglion neuronal density, and the distribution of goblet and enteroendocrine cells were tested using the Mann-Whitney test. The analyses were performed using Prism 5 software (GraphPad, San Diego, CA, USA). The level of significance was $5 \%(p<0.05)$, and the results are expressed as mean \pm standard error.

\section{RESULTS}

\section{BODY WEIGHT AND LENGTH OF THE LARGE INTESTINE}

At 90 days of age, the animals in the $\mathrm{C}$ group (fed normally) had a mean body weight of $322.3 \pm 3.35 \mathrm{~g}$. The animals in the FR group had a mean body weight of $163.4 \pm 4.8 \mathrm{~g}$, which was a statistically significant difference. The length of the large intestine was shorter $(p<0.05)$ in the FR group $(12.25 \pm 0.45 \mathrm{~cm})$ than in the $\mathrm{C}$ group $(13.75 \pm 0.41 \mathrm{~cm})$.

\section{Morphology OF THE ProXIMAL COLON}

In the histological sections stained with H\&E, we observed that FR caused no change in the structure of almost all of the layers of the wall of the proximal colon, with the exception of the tunica mucosa. The submucosa was presented reduced with intense vascularization and clear submucosal ganglia. The tunica muscularis externa was arranged in a circular inner layer and outer longitudinal layer of smooth muscle with the presence of myenteric ganglia between them, and the intestinal wall had a typical serosa.

The tunica mucosa in the animals in both groups was characterized by regular longitudinal folds and crypts lined with a single columnar epithelium, with evidence of enterocytes, goblet cells, and undifferentiated cells. However, the mucosa in the FR group presented deeper and scattered crypts, a lamina propria that was intensely populated by immune cells, mainly lymphocytes and polymorphonuclear leukocytes, and a clear, thick muscularis mucosae compared with the control animals (Fig. 1).

These changes were confirmed morphometrically by significant increases in the thickness of the tunica mucosa, crypt depth, and thickness of the muscularis mucosae and a decrease $(p<0.05)$ in the thickness of the muscularis externa (Table I).

\section{Goblet Cells (ACID AND Neutral Mucins)}

The distribution pattern of goblet cells that produce acid and neutral mucins in the intestinal crypts was similar between groups. The red-highlighted neutral mucins (PAS) were predominantly found at the apex of the crypts, and blue-highlighted acid mucins $(\mathrm{AB})$ predominated at the base of the crypts (Fig. 2a-d). With regard to the quantification of these cells, FR caused a significant reduction in the number of goblet cells that contained neutral mucins and did not change $(p>0.05)$ the number of cells with acid mucins compared with the normally fed group (Table II).

Serotoninergic Enteroendocrine Cells

Maintenance of the distribution pattern of immunoreactive serotoninergic enteroendocrine cells 
A

B

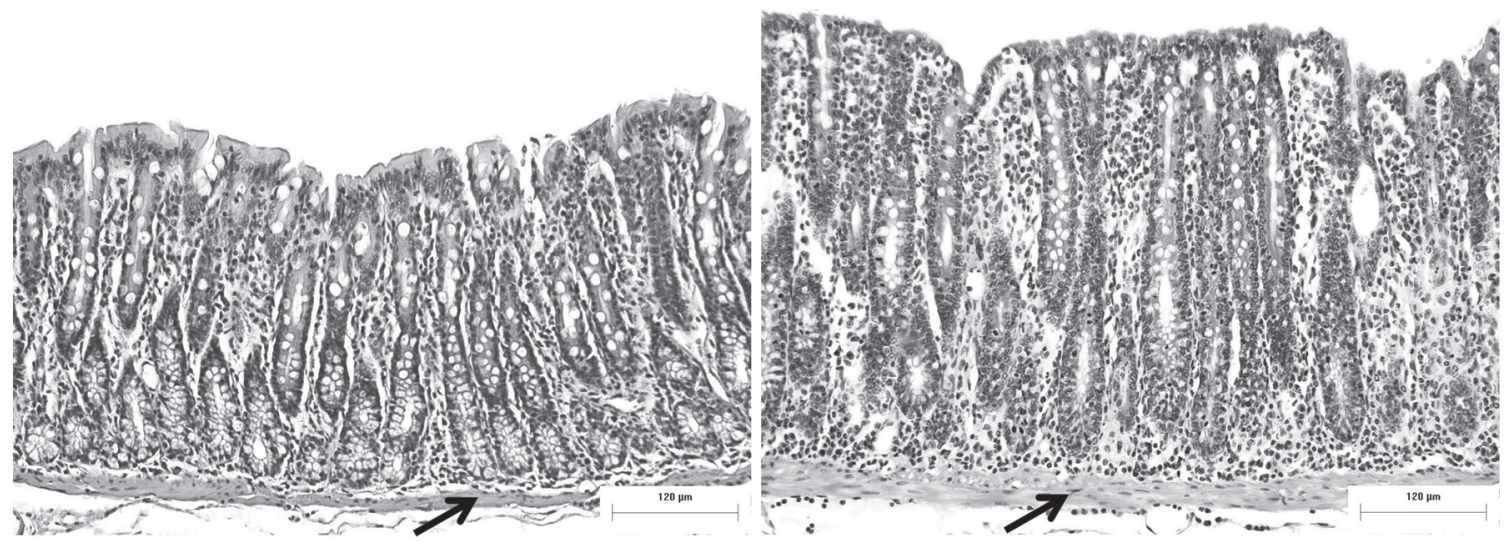

Figure 1 - Effect of food restriction on colonic mucosa. (A) Tunica mucosa of the proximal colon in control rats (C group); and (B) food-restricted rats (FR group). The arrows indicate the muscularis mucosae. Scale bar $=120 \mu \mathrm{m}$. H\&E staining.

TABLE I

Thickness of the tunica mucosa, crypt depth, thickness of the muscularis mucosae, and thickness of the muscularis externa in the proximal colon in normally fed control rats (C group) and food-restricted rats (FR group). Mean \pm standard error $(n=5)$.

\begin{tabular}{cccc}
\hline & \multicolumn{3}{c}{ Groups } \\
\cline { 2 - 4 } Morphometry $(\mu \mathrm{m})$ & $\mathrm{C}$ & FR & Variance between C and FR \\
\hline Tunica mucosa & $289.70 \pm 3.34$ & $397.80 \pm 3.58^{*}$ & $\uparrow 37.31 \%$ \\
Crypt depth & $258.00 \pm 19.68$ & $370.60 \pm 30.87^{*}$ & $\uparrow 43.64 \%$ \\
Muscularis mucosae & $11.76 \pm 1.48$ & $24.01 \pm 4.43^{*}$ & $\uparrow 104.16 \%$ \\
Muscularis externa & $307.60 \pm 1.81$ & $261.80 \pm 2.16^{*}$ & $\downarrow 14.89 \%$ \\
\hline
\end{tabular}

$* p<0.05$, significant difference compared with $\mathrm{C}$ group.

TABLE II

Number of goblet cells determined by histochemical techniques for glycoconjugates and immunoreactive serotonergic enteroendocrine cells in the mucosa of the proximal colon in normally fed control rats (C group) and food-restricted rats (FR group) in an area of $0.352 \mathrm{~mm}^{2}$. Mean \pm standard error $(n=5)$.

\begin{tabular}{cccc}
\hline & \multicolumn{3}{c}{ Groups } \\
\cline { 2 - 4 } Technique $^{\text {a }}$ & C & FR & $\begin{array}{c}\text { Variance } \\
\text { between C } \\
\text { and FR }\end{array}$ \\
\hline PAS & $215.00 \pm 4.05$ & $173.80 \pm 3.76^{*}$ & $\downarrow 19.16 \%$ \\
AB & $231.30 \pm 3.52$ & $220.50 \pm 5.12$ & ns $^{b}$ \\
Anti- & $8.04 \pm 0.22$ & $9.40 \pm 0.28^{*}$ & $\uparrow 14.46 \%$ \\
serotonin & & & \\
\hline
\end{tabular}

${ }^{a}$ PAS: Periodic Acid Schiff; AB: Alcian Blue; Anti-serotonin immunohistochemistry.

${ }^{\mathrm{b}} \mathrm{ns}$, non-significant; ${ }^{*} p<0.05$, significant difference compared with $\mathrm{C}$ group. in intestinal crypts was observed between groups, which were brown-immunostained and identified throughout the extent of the crypts of the colonic mucosa, with a higher frequency in the middle portion of the crypts (Fig. 2e, f). Food restriction affected the number of serotoninergic cells, with an increase $(p<0.05)$ in this population in the FR group compared with the control group (Table II).

\section{MYenteric NeURONAL POPULATION}

Food restriction morphologically and quantitatively interfered with the general neuronal population. A greater number of myenteric neurons was observed in the ganglion $(p<0.05)$, and a significant reduction of the mean profile area of neuronal cell bodies was found in the proximal colon in 
A

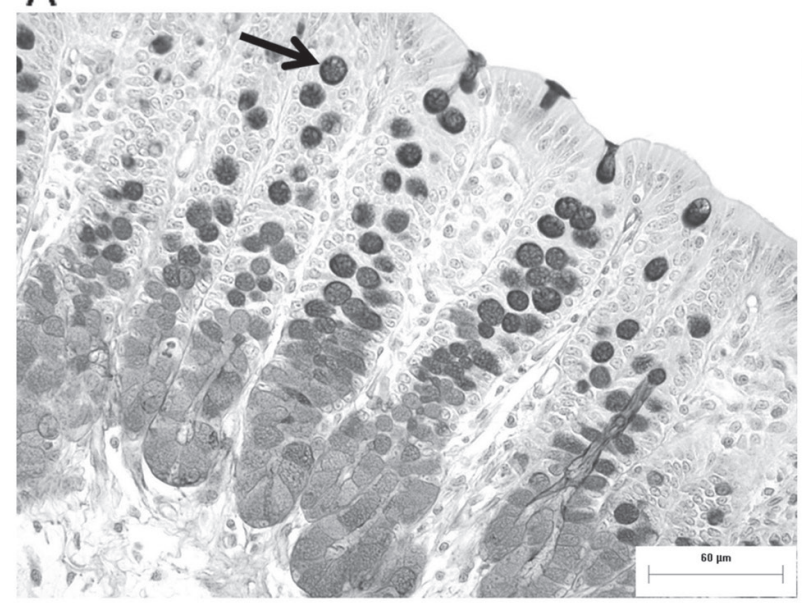

C

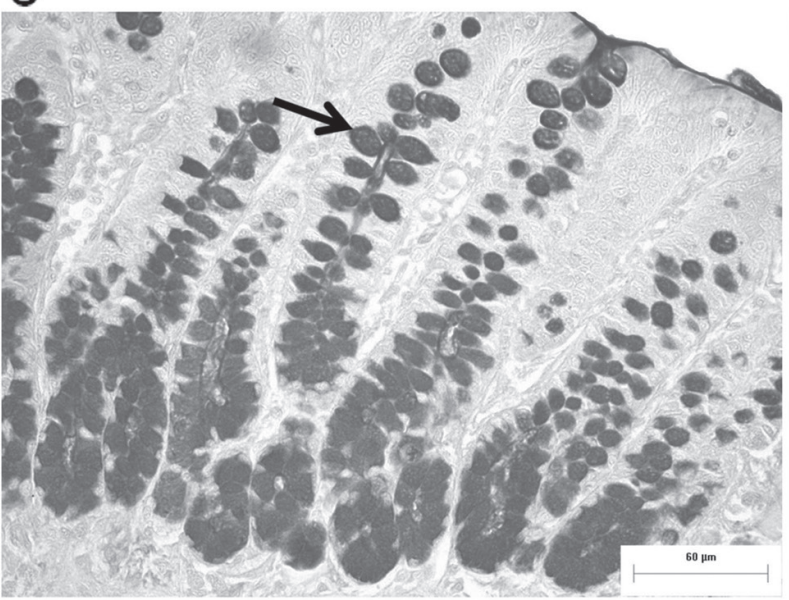

E

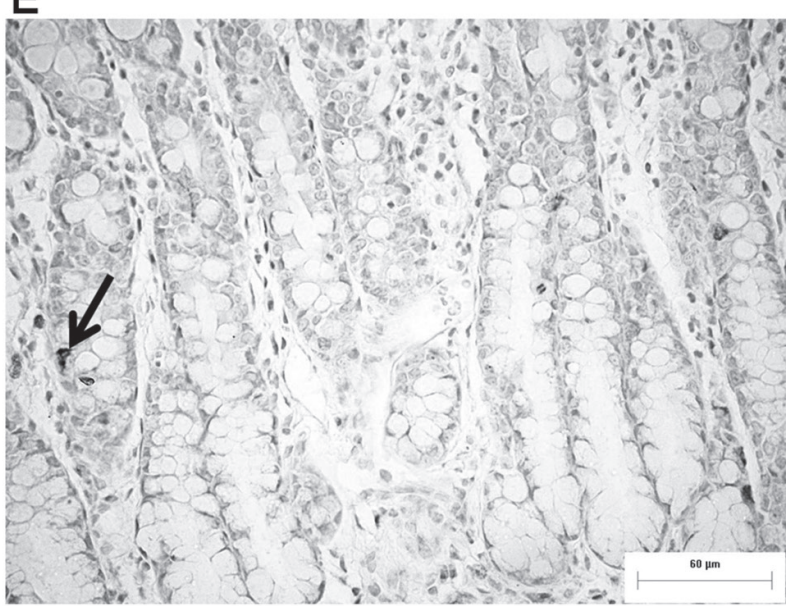

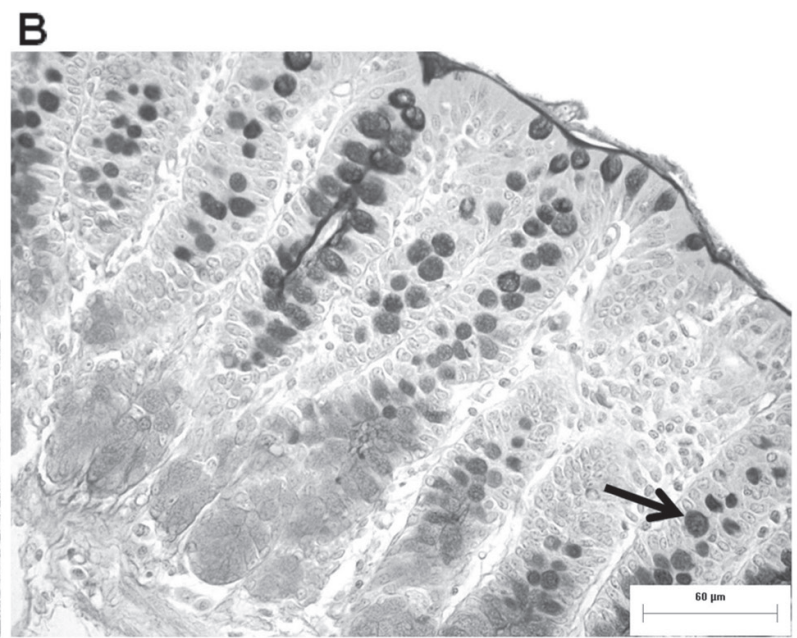

D

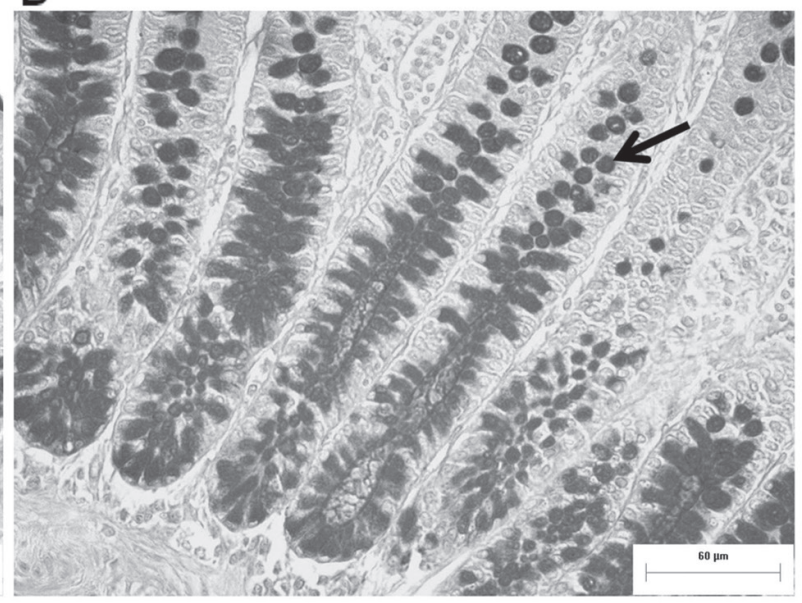

F

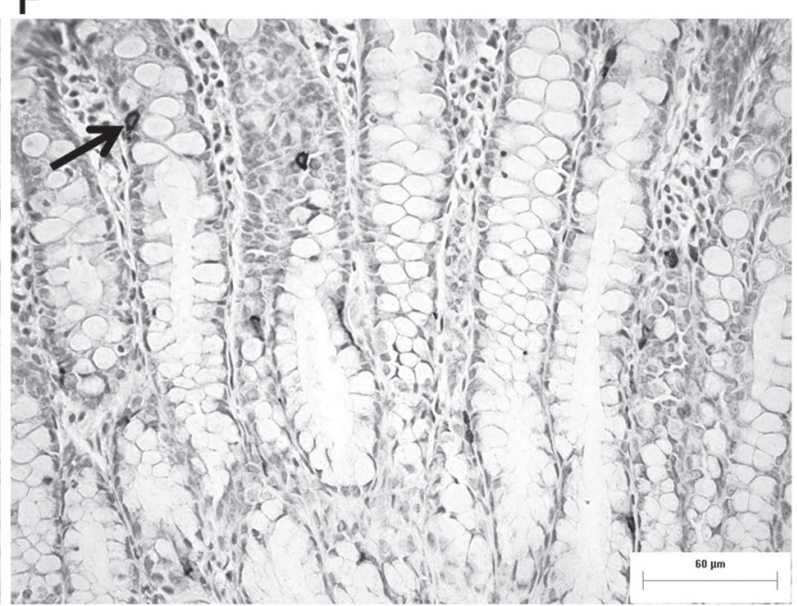

Figure 2 - Goblet cells and serotoninergic enteroendocrine cells. (A and B) Neutral mucins. (C and D) Acid mucins in goblet cells (arrows) determined by histochemical techniques (Periodic Acid Schiff [PAS] and Alcian Blue [AB], respectively). (E and F) Immunoreactive serotoninergic enteroendocrine cells (arrows) in intestinal crypts. Photomicrographs in (A, C, and E) are from the mucosa of the proximal colon in normally fed rats (C group). Photomicrographs in (B, D, and F) are from the mucosa of the proximal colon in food-restricted rats (FR group). Scale bar $=60 \mu \mathrm{m}$. 
animals subjected to FR compared with normally fed animals (Fig. 3a, b). Despite these changes, maintenance of the organization of ganglia was observed, with predominantly triangular and elongated shapes composed of neurons and glial cells (Fig. 3c).

The distribution of neurons in $150 \mu \mathrm{m}^{2}$ class intervals showed variability in the cell body area, from 24.78 to $535.95 \mu \mathrm{m}^{2}$, with a higher frequency of neurons in the $0-150 \mu \mathrm{m}^{2}$ class $(53.4 \%$ and $66.8 \%$ in the $\mathrm{C}$ and FR groups, respectively; Fig. 3d).

\section{DISCUSSION}

The FR protocol used in the present study proved the effectiveness of this model in Wistar rats. The evolution of body weight, naso-anal length, and total protein, triglyceride, and glucose levels, preliminarily performed by Vismara and Furlan (2007), indicated nutritional deficiency, with decreased body development and reduced blood glucose, although the concentration of total proteins and other blood parameters were maintained. At 90 days of age, the deficit in body weight gain in the
A

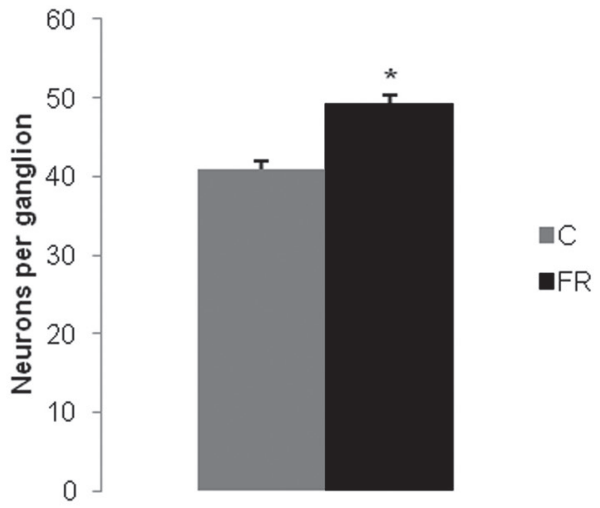

C

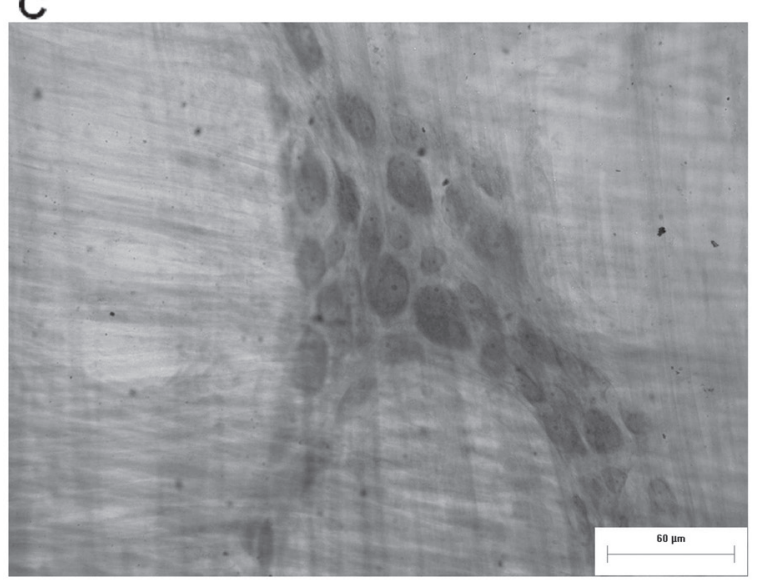

B

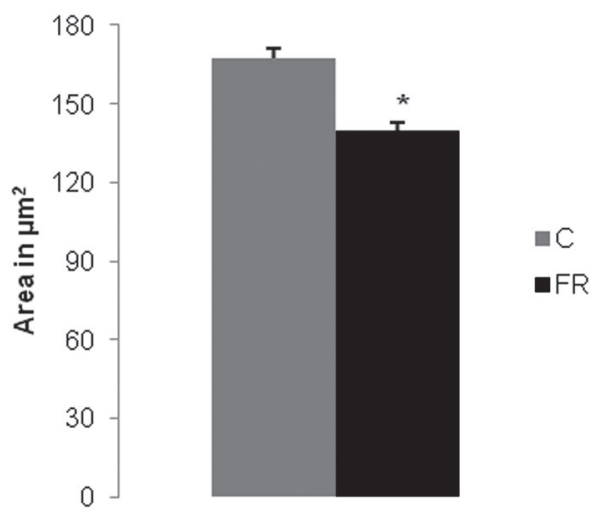

D

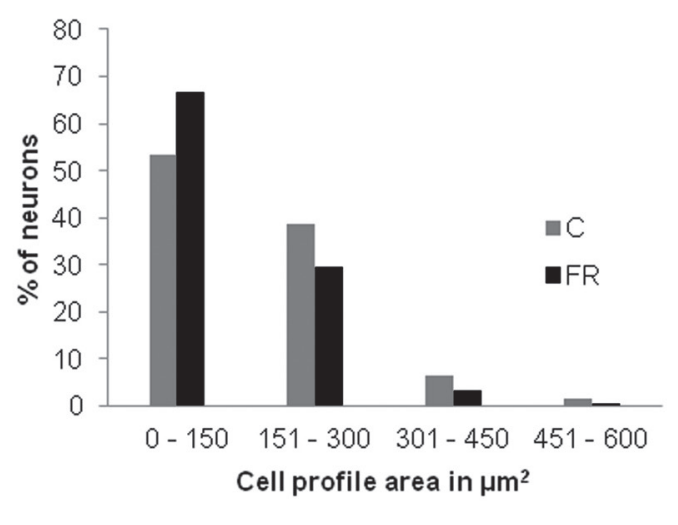

Figure 3 - Quantitative and morphometric analysis of the general myenteric neuronal population. (A) Average myenteric neurons per ganglion. (B) Profile of neuronal cell bodies $\left(\mu \mathrm{m}^{2}\right)$ of the proximal colon in control rats $(\mathrm{C}$ group) and foodrestricted rats (FR group). (C) Myenteric ganglion with neurons determined by the Giemsa technique in the proximal colon in rats in the control group (C group). (D) Frequency distribution histogram (\%) of the area of neuronal cell bodies in the proximal colon in normally fed rats (C group) and food-restricted rats (FR group). Scale bar $=60 \mu \mathrm{m} .{ }^{*} p<0.05$, significant difference compared with $\mathrm{C}$ group $(n=5)$. 
animals in the FR group was $49.3 \%$, an expected result of the diet imposed in the experimental group and frequently used in FR models (Firmansyah et al. 1989a, b, Santer and Conboy 1990, Vismara and Furlan 2007, Mazeti and Furlan 2008).

The decreased body development of the FR animals was reflected by the length of the large intestine, which showed a significant growth deficit. The lower intake of nutrients led to a targeting of these nutrients to organs that are considered vital to the survival of these animals, causing the still-growing colon structure to adapt to low nutrient availability. Nonetheless, no impairment in the function of the colon was observed, such as constipation or diarrhea. A reduction of the dimensions of the large intestine caused by a restricted food supply (Firmansyah et al. 1989a) or restricted content of protein in the diet (Sant'Ana et al. 1997, Castelucci et al. 2002, Araújo et al. 2003, Schoffen et al. 2005, Hermes et al. 2008a,b) was frequently observed. Depending on the experimental period or age of the animal, however, the large intestine can maintain or increase its dimensions.

The morphological characteristics of the layers of the proximal colon, regardless of group, were not different from other studies of the large intestine (Gartner and Hiatt 2007), especially with regard to descriptions of adult rats (LeiteMello et al. 1996). Nevertheless, the colonic mucosa in the FR group exhibited some distinct morphological characteristics. The intestinal glands classified as simple tubes (crypts) were more elongated and scattered. The lamina propria was intensely populated by immune cells, particularly polymorphonuclear lymphocytes. The colonic muscularis mucosae was clearly thicker compared with control animals.

The increase in inflammatory cells qualitatively indicates the greater vulnerability of this mucosa. Nutritional variations (Hermes et al. 2008b) and the exclusion of intestinal transit (Mello et al.
2012) lead to a reduction of the barrier formed by intestinal mucus on the mucosa of the large intestine in rats. In the colon, the mucus layer performs a lubricating function that facilitates the progression of fecal content and also provides protection against physical and chemical insult caused by microorganisms, toxins, and digestive enzymes in the intestinal lumen (Gaudier et al. 2009).

Considering that the quality and quantity of elements in the diet could modify the production of mucins in the mucosa and the composition of intestinal microbiota (Sharma and Schumacher 1995), we suggest that the lower intake of nutrients in the FR group led to a decrease in the production of neutral mucins by goblet cells but did not compromise the production of acid mucins.

With regard to the dynamics of mucin production, goblet cells in intestinal crypts begin to produce mucins at the deeper region, and this process is intensified as goblet cells approach the surface of the intestinal epithelium, demonstrated by the staining of these cells in the control group (Fig. 2a). This phenomenon is related to the maturation of goblet cells within their life cycle in the intestinal epithelium. In FR animals, the staining of neutral mucins in goblet cells was lower in the deepest region of the intestinal crypts. In addition to the reduced amount of neutral mucin-producing goblet cells, FR changed the maturation process of these cells in intestinal crypts.

The balance between the amount of acid and neutral mucins is important for the proper consistency of the mucus that lines the epithelium to fulfill its protective role against abrasion and possible deleterious effects of microbiota (Sharma and Schumacher 1995). The lower production of neutral mucins observed in FR animals may have reduced the existing interface between the mucosa and microbiota present in the large intestine, which could have activated the recruitment of immune cells in the lamina propria, a phenomenon that could explain the increased thickness of the tunica 
mucosa observed in food-restricted animals (Braga et al. 2011).

Acid mucin production has a higher energy cost compared with the production of neutral mucins. The production of the former requires further enzymatic steps for the addition of sulfate and/or sialic acid radicals. Accordingly, the animals that received lower nutrient input in the FR group may have exhibited a decrease in the production of acid mucins and not neutral mucins. Notably, neutral mucins are the most abundant subtype inside goblet cells in the GIT, accounting for approximately $80 \%$ of the total content of intestinal mucin (Gold et al. 1981). Thus, reducing the production of neutral mucins could be a strategy for lowering energy and plastic nutrient consumption when considering that the energy cost to produce neutral mucins is less, compared with the production of acid mucins.

Despite the reduction of the number of neutral mucin-producing goblet cells, the crypts in colonic mucosa were significantly larger. The increase in the crypts and consequent increase in the tunica mucosa contrast with the effects of restrictive diets on the mucosa of the small intestine (Firmansyah et al. 1989a,b, Natali et al. 1995, Torrejais et al. 1995, Franco et al. 2010). Few studies have performed this evaluation for the large intestine (Firmansyah et al. 1989a, Schoffen et al. 2005, Hermes et al. 2008b).

As previously mentioned, the increase in crypts and therefore contact surface with the external environment, may be considered an adaptive response of the organ to ensure the absorption of water and electrolytes caused by a decrease in lower intestinal length. In addition to the possible increase in the number of enterocytes to ensure absorptive function, a significant increase was observed in the number of serotoninergic cells and thickness of the muscular layer of the mucosa in the colon in the FR group.

Serotoninergic cells consist of enteroendocrine, enterochromaffin, and argentaffin cells that are located along the glands in the lamina propria of the GTI (Gartner and Hiatt 2007). Independent of the nutritional group, the current results indicated maintenance of the distribution pattern of serotoninergic enteroendocrine cells in intestinal crypts, which were brown-immunostained and were identified along the full extent of the crypts in the colonic mucosa, with a higher frequency in the middle portion. However, we verified the effect of FR on the number of serotoninergic cells, with a significant increase in this population in the FR group compared with the control group.

The impairment of the colonic mucosa (characterized by hypertrophy of the tunica mucosa, crypt hyperplasia, infiltration of immune cells in the lamina propria, and an increase in the muscularis mucosae) promoted by FR imposed, with a significant reduction in the effectiveness of the intestinal barrier, was responsible for the increase in the number of serotonergic endocrine cells. Mechanical, chemical, and nutritional stimuli and bacteria can induce the secretion of 5-HT in the intestinal wall (Fukumoto et al. 2003, Gershon 2004).

Serotonin participates in the normal and pathological functions of the intestine, including motility, secretion, and visceral perception. It regulates the growth of various tissues, including smooth muscle cells, fibroblasts, nerves, and epithelial cells in intestinal crypts (Hasler 2009). The presence of 5-HT receptors in enterocytes (Hasler 2009) suggests that the longer crypts observed in the FR group could be related to the stimulation of enteroendocrine cells, which were significantly increased and are known to generate hyperplastic crypts (Spiller 2007).

The increase in the thickness of the muscularis mucosae could also be attributable to stimulation via serotoninergic cells, because smooth muscle cells express 5-HT receptors (Hasler 2009). The contraction and relaxation of the muscularis mucosae alters the pattern of folds that facilitate uptake and secretion. The increase in the muscularis mucosae in the FR group could optimize these 
functions. A second pathway should be considered because the muscularis mucosae receives direct innervation from the submucosal plexus (Furness 2006). Submucosal neurons also express 5-HT receptors, suggesting its involvement in the mechanism of proliferation of smooth muscle cells (Spiller 2007).

Increases in the number of enteroendocrine cells and 5-HT levels are observed in patients with inflammatory bowel disease (Belai et al. 1997) and experimental models of colitis (Oshima et al. 1999, Ghia et al. 2009, Bertrand et al. 2010) and ileitis (O'Hara et al. 2004), suggesting the involvement of 5-HT in the pathogenesis of inflammation. Recent studies have shown that 5-HT participates in the activation and infiltration of immune cells in the intestinal mucosa (Bertrand et al. 2010, Ahern 2011), increasing the production of inflammatory mediators (Ghia et al. 2009) that could justify the increase in polymorphonuclear lymphocytes observed in the lamina propria of the colonic mucosa in the FR group, possibly in response to the lower effectiveness of the intestinal barrier.

Unlike the tunica mucosa, the tunica muscularis thickness was $14.89 \%$ lower in the proximal colon in FR rats. The decreased development of the tunica muscularis in small intestine segments is frequently reported in models that utilize hypoproteic diets (Torrejais et al. 1995, Franco et al. 2010), but the tunica muscularis of the colon is slightly altered (Schoffen et al. 2005, Hermes et al. 2008b). This result can be explained by the lower supply of nutrients caused by FR, such as a reduced availability of amino acids, which can affect protein synthesis in intestinal muscles and support the occurrence of muscle atrophy. Another factor that could explain this result is an increase in protein degradation in this muscle to provide endogenous amino acids and offset the low consumption of these molecules through the diet (Araújo et al. 2003). This may make endogenous amino acids available to tissues (e.g., mucosa and nerve cells) with an increased need for protein synthesis before the nutritional condition imposed.

Despite the proven existence of 5-HT receptors in intestinal smooth muscles (Hasler 2009) and in contrast to the increase in the muscularis mucosae thickness, we can exclude the possibility that the colonic external muscle atrophy observed in FR animals is modulated by the secretion of 5-HT in enteroendocrine cells because the receptors in this intestinal tunica play an important role in peristalsis. They contribute to circular muscle relaxation by acting as a target for endogenous 5-HT secreted by both neuronal and enteroendocrine cells (Tonini et al. 2005). No studies have established a relationship between atrophy of the muscular tunica and serotoninergic enteroendocrine cells.

Moreover, we should consider the influence of intrinsic innervation mainly of the myenteric plexus on muscle tissue. According to Gabella (1987), muscle volume, innervation, and myenteric neuronal plasticity are closely related to each other. Changes in the volume of smooth muscle tissue can promote an increase or decrease in the number and size of the cell body of myenteric plexus neurons.

Food restriction imposed since lactation until adulthood (90 days of age) significantly interfered with the general neuronal population stained using the Giemsa method. A greater number of myenteric neurons was found in the ganglia of the proximal colon in animals subjected to the restrictive diet compared with control animals. In contrast to our results, Santer and Conboy (1990) reported that FR from gestation until postnatal day 140 reduced the number of NADH-diaphorase-positive myenteric neurons by $27 \%$ in the jejunum in rats. We infer that the difference in the neural response between these studies is attributable to the time of dietary restriction and the trial period or the intestinal segment and neuronal phenotype analyzed.

A low-protein diet given to animals at different stages of development (e.g., gestation, lactation, and adulthood) may lead to reduced intestinal size, 
resulting in a higher concentration of neurons per area in segments of the small intestine (Torrejais et al. 1995, Natali and Miranda-Neto 1996, Natali et al. 2003) and colon (Leite-Mello et al. 1997, Sant'Ana et al. 1997, Castelucci et al. 2002, Araújo et al. 2003, Hermes et al. 2008a). In the present study, we cannot attribute the intestinal reduction to the higher number of neurons observed in the FR animals compared with normally fed animals because the quantification of these cells was performed per myenteric ganglion and not per intestinal area. Thus, a greater number of neurons was present in the proximal colon in adult rats subjected to FR since lactation.

Although the ENS is sufficiently well-developed from birth, such a system in animal or human newborns is not yet fully mature and continues to develop after birth (Gershon 2000). During postnatal development in rats, reductions of neuronal density are observed in the small (Gabella 1971, Marese et al. 2007) and large (Vries et al. 2010) intestines, and numerical stability is achieved from 60 to 90 days of age (Marese et al. 2007). We consider that the significant $16.20 \%$ increase in the neuronal density of the ganglia in the proximal colon in the FR group compared with the control group is related to the increased number of serotoninergic enteroendocrine cells. Serotonin acts as a growth factor that promotes development (Fiorica-Howells et al. 2000, Gershon 2000, 2013), neurogenesis (Liu et al. 2009), and an increase in the survival and plasticity (Li et al. 2011) of ENS neurons.

The ability of a neurotransmitter or paracrine factor, such as 5-HT, to affect enteric neuronal development, demonstrates the potential impact that the immature intestine has on this system (Fiorica-Howells et al. 2000, Gershon and Tack 2007). Serotoninergic neurons are among the first to emerge during development, and they promote the development and survival of other classes of enteric neurons (Li et al. 2011, Gershon 2013). Therefore, the activity of the first nerve and enteroendocrine cells during development could affect the number and phenotypic composition of ENS neurons in the adult animal (Gershon and Tack 2007).

Under normal or pathological conditions, the mucosa induces the paracrine secretion of 5-HT by enteroendocrine cells. Secretory and motor reflexes occur through contacts with receptors on nerve endings located in the lamina propria (Gershon 2000). Once secreted, 5-HT stimulates intrinsic primary afferent neurons of the myenteric and submucosal plexus and consequently activates interneurons and excitatory and inhibitory motor neurons in tissues or effector target cells ( $\mathrm{Li}$ et al. 2011). During development, the neurotransmitters released by stimulated nerve cells (by 5-HT and other neurotransmitters) determine the degree of activity of other neurons, thereby regulating the activity of these cells and exerting positive or negative effects on the development of the ENS (Gershon 2000).

Based on the action of 5-HT on the intestinal wall, our results suggest that the increased number of serotoninergic enteroendocrine cells observed in experimental FR animals, stimulates primary afferent neurons of the myenteric ganglion and maintain the activity of a higher number of nerve cells that depend on this stimulus, thus enhancing the survival or plasticity of intrinsic colonic innervation by altering the normal development and postnatal maturation of the myenteric plexus.

Therefore, 5-HT did not appear to induce enteric neurogenesis from stem cells in the intestine in our experimental animals, in contrast to those observed in adult mice (Liu et al. 2009). In contrast to mice, rats exhibit a postnatal reduction of myenteric neuronal density (Gabella 1971, Marese et al. 2007, Vries et al. 2010), with no evidence of neurogenesis when subjected to FR (Santer and Conboy 1990). Another possibility that can also be rejected is the neuroprotective effect of the imposed diet, a result commonly observed in the intestine in rats during the aging process (Cowen et al. 2000, Porto et al. 2012). Our animals were in 
young adulthood and were still undergoing growth and maturation processes.

Changes in the cellular profile area of enteric neurons can occur in response to changes in the lumen of the GIT (Giancamillo et al. 2010). Our results indicate that FR reduced the area of the cellular profile of myenteric neurons in the proximal colon, which is consistent with results obtained in segments of the large intestine (Sant'Ana et al. 1997, Castelucci et al. 2002) and small intestine (Torrejais et al. 1995, Natali et al. 2003) in undernourished rats during pregnancy, lactation, and adulthood. Thus, the neuronal atrophy observed with FR was probably attributable to a reduction of the capacity for structural protein synthesis, a decrease in cellular activity, or an adaptive response to low nutrient input received by the nutritional condition imposed.

Furthermore, the reduced size of neuronal cell bodies is a compensatory mechanism related to the amount of myenteric neurons. A larger number of nerve cells in ganglia and a reduction of the thickness of the tunica muscularis results in a lower functional demand for these neurons to maintain the motility of the proximal colon, a fact that can trigger the neuronal atrophy observed in the present study.

The animals in this study exhibited a healthy appearance and no evidence of physiological disorders that involve the GIT, despite the atrophy of neuronal cell bodies and muscularis externa. According to Sjolund et al. (1997), however, an increase in the number of serotoninergic enteroendocrine cells in the colon in humans is associated with slow-transit constipation.

The experimental animals were subjected to a prolonged and severe restrictive diet during a critical period of body growth and maturation of the intestines and ENS. The changes observed in colonic morphology and intrinsic innervation in young adult rats may reflect the importance of a balanced diet beginning with lactation, for effective development and the proper morphology and physiology of the entire GIT and other organ systems.
Based on these results, the FR imposed since lactation altered the morphology of the proximal colon in adult rats, with cellular hypertrophy of the tunica mucosa, a decrease in the production of neutral mucins, and atrophy of the tunica muscularis. Food restriction also increased the cell survival rate and atrophy of the myenteric neuronal population, demonstrating the adaptive effort made by the animal to maintain the proper functioning of the colon.

\section{ACKNOWLEDGMENTS}

The authors were financially support by the Conselho Nacional de Desenvolvimento Científico e Tecnológico (CNPq) and Fundação Araucária. The authors acknowledge the technical support of laboratories of Animal Histotechnique and Physiology, Universidade Estadual de Maringá, Brazil.

\section{RESUMO}

Estudaram-se os efeitos da restrição alimentar (RA) sobre aspectos morfoquantitativos da parede e dos neurônios mioentéricos do colo proximal de ratos adultos. A RA foi imposta por duplicação do tamanho da ninhada experimental em relação à ninhada controle durante a lactação, e por redução de $50 \%$ na ração ofertada desde o desmame até os 90 dias de idade. Amostras do colo foram destinadas a processamento histológico para análise morfométrica das criptas, camada muscular da mucosa e das túnicas mucosa e muscular externa; determinação do número de células caliciformes e células enteroendócrinas serotoninérgicas e estudo morfoquantitativo da população neuronal mioentérica. A dieta restritiva causou hipertrofia na túnica mucosa, aumento na profundidade das criptas, na camada muscular da mucosa, redução na espessura da túnica muscular, no número de células caliciformes e aumento na quantidade de células serotoninérgicas. Maior densidade neuronal nos gânglios e redução na área do perfil celular foram constatados nos animais RA. A RA imposta desde o período de lactação provoca hipertrofia da túnica mucosa, redução da produção de 
mucinas neutras, atrofia da túnica muscular e aumento na sobrevivência neuronal de ratos adultos, decorrente da maior quantidade de células enteroendócrinas serotoninérgicas presentes na mucosa.

Palavras-chave: células enteroendócrinas, restrição alimentar, células caliciformes, morfologia intestinal, neurônios mioentéricos, serotonina.

\section{REFERENCES}

AHERn GP. 2011. 5-HT and the immune system. Curr Opin Pharmacol 11: 29-33.

ARAÚJo EJA, SANT'ANA DMG, MOLINARI SL AND MIRANDANETO MH. 2003. Effect of protein and vitamin B deficiency on the morphoquantitative aspects of the myenteric plexus of the descending colon of adults rats. Arq Neuropsiquiatr 61: 226-233.

BARBOSA AJA. 1978. Técnica histológica para gânglios nervosos intramurais em preparados espessos. Rev Bras Pesqui Med Biol 11: 95-97.

Belai A, Boulos PB, Robson T and Burnstock G. 1997. Neurochemical coding in the small intestine of patients with Crohn's disease. Gut 40: 767-774.

Berthoud HR AND NeuHuber WL. 2000. Functional and chemical anatomy of the afferent vagal system. Auton Neurosci 85: 1-17.

BERTRAND PP, BARAJAs-EspinOSA A, Neshat S, BERTRAND RL AND LOMAX AE. 2010. Analysis of real-time serotonin (5-HT) availability during experimental colitis in mouse. Am J Physiol Gastrointest Liver Physiol 298: G446-G455.

Braga CF, Silva AV, SANT'Ana DMG AND AraúJo EJA. 2011. Infecção toxoplásmica causa hipertrofia da parede do cólon de frangos. Arq Bras Med Vet Zootec 63: 340347.

CAstelucci P, Souza RR, Angelis RC, Furness JB AND LIBERTI EA. 2002. Effects of pre- and postnatal protein deprivation and postnatal refeeding on myenteric neurons of the rat large intestine: a quantitative study. Cell Tissue Res 310: 1-7.

Christensen J. 1989. Colonic motility. In: SCHULTZ, S.G. (Eds). Handbook of physiology: the gastrointestinal system, Maryland: American Physiological Society, Maryland, USA, p. 939-973.

Corfield AP, Myerscough N, LONGMAN R, Sylvester P, ARUl S AND Pignatelli M. 2000. Mucins and mucosal protection in the gastrointestinal tract: new prospects for mucins in the pathology of gastrointestinal disease. Gut 47: 589-594.

COWEn T, Johnson RJ, SOUBEyre V AND SANTER RM. 2000. Restricted diet rescues rat enteric motor neurons from age related cell death. Gut 47: 653-660.

CROWELL MD. 2004. Role of serotonin in the pathophysiology of the irritable bowel syndrome. Brit J Pharmacol 141: 1285-1293.
FIORICA-Howells E, MAROTEAUX L AND GERSHON MD. 2000. Serotonin and the 5-HT(2B) receptor in the development of enteric neurons. J Neurosci 20: 294-305.

Firmansyah A, Suwandito L, Penn D and Lebenthal E. 1989a. Biochemical and morphological changes in the digestive tract of rats after prenatal and postnatal malnutrition. Am J Clin Nutr 50: 261-268.

FIRMANSYAH A, SUNOTO S AND SUHARYONO W. 1989b. Effect of malnutrition during different periods on the small intestine of the rat. Jpn J Exp Med 59: 1-7.

Franco CLM, SANT'ANA DMG AND ARAÚJO EJ. 2010. Intestinal wall atrophy and increase of sulphomucin secretion in the jejunal epithelium of rats submitted to severe protein malnutrition. Int J Morphol 28: 497-502.

FUKUMOTO S, TATEWAKI M, YAMADA T, FUJIMIYA M, MANTYH C, VOSS M, EUBANKS S, HARRIS M, PAPPAS TN AND TAKAHASHI T. 2003. Shortchain fatty acids stimulate colonic transit via intraluminal 5-HT release in rats. Am J Physiol Regul Integr Comp Physiol 284: R1269-R1276.

FURNESS JB. 2006. The enteric nervous system. Maden: Blackwell Publishing, $274 \mathrm{p}$.

Gabella G. 1971. Neuron size and number in the myenteric plexus of the newborn and adult rat. J Anat 109: 81-94.

GABELLA G. 1987. Structure of muscles and nerves in the gastrointestinal tract. In: JOHNSON LR. Physiology of the gastrointestinal tract, $2^{\text {nd }}$ ed., New York: Raven Press, p. 335-381.

GARTNER LP AND HiATt JL. 2007. Tratado de histologia em cores, $3^{\text {rd }}$ ed., Rio de Janeiro: Elsevier, 456 p.

GAUdiER E, Rival M, BUISINE MP, ROBINEAU I AND HOEBLER C. 2009. Butyrate enemas upregulate Muc genes expression but decrease adherent mucus thickness in mice colon. Physiol Res 58: 111-119.

GERSHON MD. 2000. O segundo cérebro. Rio de Janeiro: Campus, $350 \mathrm{p}$.

GERSHON MD. 2004. Review article: serotonin receptors and transporters - roles in normal and abnormal gastrointestinal motility. Aliment Pharmacol Ther 20: 3-14.

GERSHON MD. 2013. 5-Hydroxytryptamine (serotonin) in the gastrointestinal tract. Curr Opin Endocrinol Diabetes Obes 20: 14-21.

GERSHON MD AND TACK J. 2007. The serotonin signaling system: from basic understanding to drug development for functional GI disorders. Gastroenterology 132: 397-414.

GHIA JE, Li N, WANG H, COLLINS M, DENG Y, El-SharkaWy RT, Cote F, Mallet J AND Khan WI. 2009. Serotonin has a key role in pathogenesis of experimental colitis. Gastroenterology 137: 1649-1660.

Giancamillo AD, Vitari F, Bosi G, SAVoini G AND DomeneGHini C. 2010. The chemical code of porcine enteric neurons and the number of enteric glial cells are altered by dietary probiotics. Neurogastroenterol Motil 22: 271-278.

Gold DV, Shochat D AND Miller F. 1981. Protease digestion of colonic mucin. Evidence for the existence of two immunochemically distinct mucins. J Biol Chem 25: 6354-6358. 
HANSEN MB. 2003. The enteric nervous system I: organisation and classification. Pharmacol Toxicol 92: 105-113.

HASLER WL. 2009. Serotonin and the GI tract. Curr Gastroenterol Rep 11: 383-391.

Hermes C, Almeida EC, Souza EA, AraúJo EJA AND SANT'ANA DMG. 2008a. Efeitos da desnutrição protéica severa sobre aspectos morfológicos e quantitativos dos neurônios mientéricos do colón ascendente de ratos. Arq Ciênc Vet Zool Unipar 11: 5-10.

Hermes C, Azevedo JF, Araújo EJA And SANT'AnA DMG. 2008b. Intestinal ascending colon morphometrics in rats submitted to severe protein malnutrition. Int J Morphol 26: 5-11.

Leite-Mello EVS, Miranda-Neto MH AND Natali MRM. 1996. Morfologia do colo proximal de ratos. Rev Unimar 18: 369-386.

Leite-Mello EVS, Stabille SR AND Miranda-Neto MH. 1997. Effect of maternal protein deprivation on morphological and quantitative aspects of the myenteric plexus neurons of proximal colon in rats. Arq Neuropsiquiatr 55: 106-113.

Li Z, Chalazonitis A, Huang Y, Mann JJ, Margolis KG, YANG QM, KIM DO, Côté F, MALlet J AND GERSHON MD. 2011. Essential roles of enteric neuronal serotonin in gastrointestinal motility and the development/survival of enteric dopaminergic neurons. J Neurosci 31: 8998-9009.

LiU MT, KUAN YH, WANG J, HEN R AND GESHON MD. 2009. 5-HT4 receptor-mediated neuroprotection and neurogenesis in the enteric nervous system of adult mice. J Neurosci 29: 9683-9699.

MARESE ACM, Freitas P AND NATALI MRM. 2007. Alterations of the number and the profile of myenteric neurons of Wistar rats promoted by age. Auton Neurosci 137: 10-18.

MAZETI CMAND FURLAN MM. 2008. Crescimento e parâmetros reprodutivos de ratas Wistar sob restrição alimentar desde o nascimento. Acta Sci Biol Sci 30: 197-204.

Mello RO, Silva CMG, Fonte FP, Silva DLF, Pereira JA, MARGARIDO NF AND MARTINEZ CAR. 2012. Avaliação do número de células caliciformes nas criptas da mucosa colônica com e sem trânsito intestinal. Rev Col Bras Cir 39: 139-145.

NATALI MRM AND MiRANDA-Neto MH. 1996. Effect of maternal proteic undernutrition on the neurons of the myenteric plexus of the duodenum of rats. Arq Neuropsiquiatr 54: 273-279.

NATALI MRM, MiRANDA-NETO MH, BALHS AS AND WATANABE I. 1995. Effects of maternal protein malnutrition on the duodenal mucous layer of rats. Braz $\mathrm{J}$ Morphol Sci 12: 71-76.

NATALI MRM, MiRANDA-Neto MH AND ORSI AM. 2003. Morphometry and quantification of the myenteric neurons of the duodenum of adult rats fed with hypoproteic chow. Int J Morphol 21: 273-277.

O'HARA JR, Ho W, LINDEN DR, MAWE GM AND SHARKEY KA. 2004. Enteroendocrine cells and 5-HT availability are altered in mucosa of guinea pigs with TNBS ileitis. Am J Physiol Gastrointest Liver Physiol 287: G998-G1007.
Oshima S, FuJimura M AND FuJIMIYA M. 1999. Changes in number of serotonin-containing cells and serotonin levels in the intestinal mucosa of rats with colitis induced by dextran sodium sulfate. Histochem Cell Biol 112: 257-263.

Ovalle WK AND NAHIRNEY PC. 2008. Netter bases da histologia. Rio de Janeiro: Elsevier, 493 p.

Porto GS, Pereira JNB, Tibúrcio VG, Stabille SR, FAria HG, Germano RM AND Mari RB. 2012. Effect of caloric restriction on myenteric neuroplasticity in the rat duodenum during aging. Auton Neurosci 168: 43-47.

RAYBOULD HE. 2002. Visceral perception: sensory transduction in visceral afferents and nutrients. Gut 51: i11-i14.

SANT'ANA DMG, MiRANDA-Neto MH, SOUZA RR AND MOLINARI SL. 1997. Morphological and quantitative study of the myenteric plexus of the ascending colon of subjected to proteic desnutrition. Arq Neuropsiquiatr 55: 687-695.

SANTER RM AND CONBOY VB. 1990. Prenatal undernutrition permanently decreases enteric neuron number and sympathetic innervation of Auerbach's plexus in the rat. J Anat 168: 57-62.

SCHOFFEN JPF, SOARES A, FreITAS P, BUTTOW NC AND NATALI MRM. 2005. Effects of a hypoproteic diet on myosin-V immunostained myenteric neurons and the proximal colon wall of aging rats. Auton Neurosci 122: 77-83.

SHARMA R AND SCHUMACHER U. 1995. Morphometric analysis of intestinal mucins under different dietary conditions and gut flora in rats. Dig Dis Sci 40: 2532-2539.

SJOLUnd K, FASTh S, EKMAN R, Hulten L, JibORN H, NoRDGREN S AND SUNDLER F. 1997. Neuropeptides in idiopathic chronic constipation (slow transit constipation). Neurogastroenterol Motil 9: 143-150.

SPILLER R. 2007. Recent advances in understanding the role of serotonin in gastrointestinal motility in functional bowel disorders: alterations in 5-HT signalling and metabolism in human disease. Neurogastroenterol Motil 19: 25-31.

TAKANO J. 1964. Intestinal changes in protein-deficient rats. Exp Mol Pathol 3: 224-231.

Tonini M, Vicini R, CERVIo E, Ponti F, Giorgio R, BARBARA G, Stanghellini V, Dellabianca A And Sternini C. 2005. 5-HT7 Receptors modulate peristalsis and accommodation in the guinea pig ileum. Gastroenterology 129: $1557-1566$.

TORREJAIS MM, NATALI MRM, CONEGERO CI AND MIRANDANETO MH. 1995. Effect of proteic malnutrition after breast-feeding on the morphology of the intestinal wall and myenteric neurons of the ileum of rats. Rev Unimar 17: 315-327.

VISMARA MR AND FURLAN MM. 2007. Parâmetros biométricos como indicadores do grau de desnutrição em ratos sob restrição alimentar desde o nascimento. Arq Ciênc Saúde Unipar 11: 3-8.

VRies P, Soret R, Suply E, Heloury Y AND Neunlist M. 2010. Postnatal development of myenteric neurochemical phenotype and impact on neuromuscular transmission in the rat colon. Am J Physiol Gastrointest Liver Physiol 299: G539-G547. 
